\title{
INHERITANCE OF A MOSAIC PERICARP PATTERN COLOR OF MAIZE
}

\author{
H. K. HAYES \\ Minnesota Experiment Station, St. Paul, Minnesota
}

[Received January 18, 1917]

TABLE OF CONTENTS

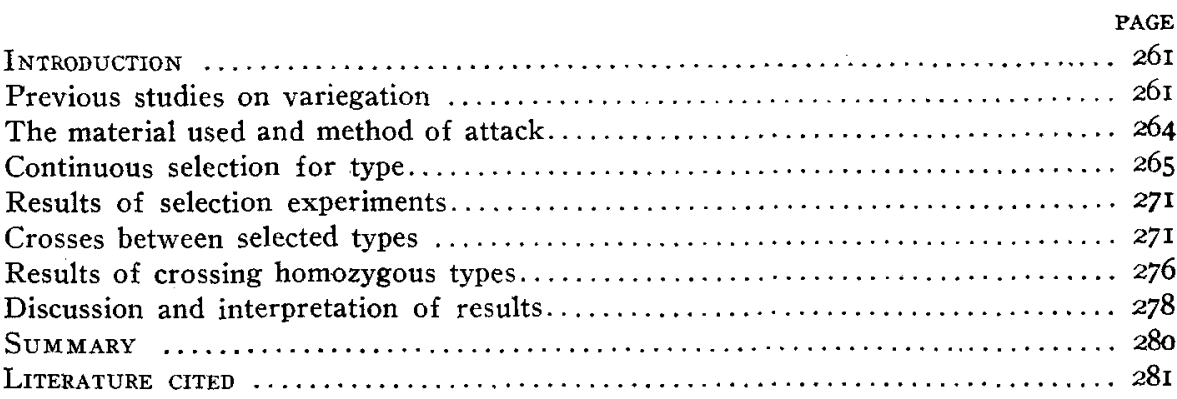

\section{INTRODUCTION}

Selection experiments for the purpose of testing JoHAnnsen's pure line hypothesis have given radically different results. In some cases selection within the pure line has served to isolate new types in which the character studied is progressively changed in the direction of the selection (JENNINGS 1916). In other experiments continued selection of plus and minus variates has not altered the mean of the progeny to any appreciable extent. This would indicate that some characters are in a much more stable condition than others. Mosaic or variegated pattern colors are examples of characters which exhibit a high degree of variability. For this reason carefully planned selection experiments with this class of characters should be of especial interest. The purpose of this paper is to describe experiments with a mosaic pericarp pattern color of maize.

\section{PREVIOUS STUDIES ON VARIEGATION}

DE VRIES (I9IO, pp. II3-I60) carried on a number of experiments with variegated flowers. A brief summary of his work with Antirrhinum

1 Published with the approval of the Director as paper No. 56, Journal Series of the Minnesota Agricultural Experiment Station. 
majus luteum striatum shows the general nature of his results. He found the variety striatum to be an inconstant race. There was found to be a continuous range of variation from narrow- to broad-striped forms. The narrowly striped forms gave only a small percentage of self red types (from 2 to 5 ). The broadly striped individuals gave a percentage of from I I to 42 self red individuals. The self red form obtained from variegated parentage gave a progeny of about 25 percent variegated and 75 percent red. This variegated type is an example of an "eversporting variety." This term is applied to a race "which produces in every generation a fairly constant proportion of atavists."

CoRrens (I9IO) reported a study of the inheritance of the self green condition which appeared as a bud sport on variegated-leaved plants of Mirabilis. The green branches gave a progeny of about 75 percent green and 25 percent variegated. Of the 75 percent green plants approximately one-third bred true for self green and two-thirds again gave 75 percent green and 25 percent variegated.

EAst and HAyes (I9II) report the case of an ear which was found in a field of dent maize of unknown parentage. This ear had seeds with a red pericarp on one side and seeds which were white or had a narrow red stripe on the other side. As no other red ears appeared in the field, it was supposed that this ear was nearly all pollinated by white. The red seeds gave a progeny of 50 percent red ears and $5^{\circ}$ percent white ears. The white and striated seeds gave 50 percent ears with some striated seeds and 50 percent with white seeds. The result was explained on the basis that the plant due to produce a red ear varied somatically so that a part of the ear was red the other part white and striated.

Emerson (I9I4) reports experiments with a recurring somatic variation in variegated ears of "Calico" dent corn, Zea mays indentata. The variegated condition is the result of stripes of red occurring on the pericarp of the seeds, the remaining area being colorless or showing a sort of washed out red. In some cases there were seeds with a colorless pericarp and also seeds with self red pericarp scattered over the same ear. Rarely, freak ears were found with a patch of self red or nearly self red grains. The number and width of the red stripes were very variable, the range of variation being from ears with only a single narrow stripe on one seed to ears with a few seeds striped, the remaining seeds having a self red pericarp.

Self-fertilized ears of this variegated race were obtained and seeds with various amounts of red were selected. The results showed that the more red there was in the seed planted the larger the percentage of red 
ears in the progeny. The pollination of an uncolored race by the variegated race gave about $\mathrm{I} 2$ percent self red ears which showed that some of the male gametes of the variegated race carried factors for self red.

The red ears obtained from self-fertilized seed of homozygous variegated ears behaved as if they were $F_{1}$ crosses between red-eared and variegated-eared races, and gave a progeny with a ratio of approximately three self red ears to one variegated ear. In later generations a portion of the self red ears bred true.

EMERSON concludes that the fact that variegated plants occasionally produce self red ears is not in general to be taken as an indication that the variegated plants in question are heterozygous, but that such behavior seems to be inseparably associated with variegation. His results are explained on the hypothesis that in a homozygous race, one of the factors for variegation $V$ changes to a factor for self color or $S$. No attempt is made to explain the cause of this change, although the author mentions the possibility that this is due to changing metabolic processes in the maturing plant, or to external influences, or to a quality inherent in the factor itself. Emerson shows that the results of DE VRIES, Correns, and EAST and HAYES, can be explained in a similar manner.

The recent experiments by STout (I9I5) on selection of somatic variations show that variegated pattern colors of Coleus are very variable. $\mathrm{He}$ found that bud variations were common and the conclusion was reached that "in Coleus asexual and sexual reproduction were not fundamentally different in respect to the extent and range of variation." Sexual reproduction produced all types of variation in $F_{1}$, which shows that the characters dealt with were heterozygous. No evidence was found of the somatic segregation of invariable pattern factors. This was thought to be due to the fundamental relations between the chemical compounds involved.

On submitting this paper for publication the author learned that a further study with variegated pattern colors of dent maize had been made by EMERson and would appear in an early number of Genetics. These recent investigations (EMERSON I9I7) were made by pollinating the progeny of variegated maize races by colorless strains. A careful separation of the seeds of the ears thus obtained was made. "Selfcolored, partly self-colored, variously variegated and colorless seeds from variegated parent ears, thus pollinated, have given progenies containing a percentage of self-colored ears roughly proportional to the amount of self color in the seeds planted."

Evidence is given for two, and possibly more, distinctly different types 
of variegation. The two types which were clearly demonstrated were called very light variegated and medium variegated. The very light variegated type, $V_{l} V_{l}$, "has little red (or brown) color-few more or less fully self-colored seeds and few even that are prominently striped with color-because the factor concerned changes to a factor for self color comparatively rarely." The medium variegated type has more self-colored seeds because the factor for medium variegation, $V_{m} V_{m}$, more frequently changes to the self color condition.

EMERSON concludes that there is a series of nine or ten multiple allelomorphs to which variegation belongs and that these various factors are a result of several mutations from an original factor. Some of these factors mutate frequently, others rarely and still others have never been observed to mutate. The more distinct types of variegation are inherited in a simple Mendelian way, without apparently any evidence of contamination.

EMERSON has used the term sporophytic variation in the place of somatic variation for that class of changes which occur in meristematic cells from which later arise the germ cells as well as the somatic tissues in which the variation is exhibited.

\section{THE MATERIAL USED AND METHOD OF ATTACK}

The material used for the present study belongs to the subspecies $Z_{\mathfrak{c} a}$ mays indurata. It was known as "Brindle flint" and did not prove to be homozygous for the character from which it takes its name. The mosaic pericarp is formed by either narrow or broad red stripes extending irregularly from the point of attachment of the silk. The ear appears as dark, medium, or light, mosaic, with the variation in number and width of these red slashes.

As the material did not breed true for the character to be studied (I909-'Io) it was decided to attempt the production of homozygous races by self-fertilization.

The field technique has been described in a previous publication (EAsT and HAyes I9I $\mathbf{r}$ ). At this time a determination was made of the degree of experimental error during pollination. Twenty-five ears were handled in the same way as if pollination was to be made, with the exception that no pollen was applied. Of these twenty-five ears $\mathrm{r} 6$ produced no seeds; three ears produced one seed each; four ears produced two seeds each; while one ear produced five seeds. Thus the experimental error is probably less than one seed per ear with a maximum error of five to six seeds per ear. 
For the first six years (I909-I9I4) the work was carried on at the Connecticut Experiment Station. Since 19 I 5 it has been conducted at the Minnesota Experiment Station.

The author wishes to acknowledge his indebtedness to Mr. C. D. HuBbell and Mr. A. F. Schultz of the Connecticut Experiment Station and Mr. P. J. Olson of the Minnesota Experiment Station for aid in the field work involved.

\section{CONTINUOUS SELECTION FOR TYPE}

The first two years of the experiment (I909-IO) showed that all ranges of variation from dark, heavily striped ears to colorless-pericarp ears could be obtained. It is worthy of note that no self red ears appeared in either year in a total progeny of 188 ears.

From I9I I to I9I6 selection experiments were carried on for the purpose of isolating pure types. The parental ears used were self-pollinated in all cases. Eight classes were used for the description of the progeny according to the amount of variegation of the ears obtained. These classes for pericarp color were: Self red, deep mosaic some seeds self, deep mosaic, medium mosaic, light mosaic, few seeds striped, very slight pattern, and colorless. In addition a record of bud sports was kept showing the somatic variation involved. The self red class consisted of ears in which all seeds were uniformly covered with a red pericarp. In the deep mosaic some seeds self class were placed all ears in which a portion of the seeds were very heavily striped, the remaining seeds having a self red pericarp. The classes, deep mosaic, medium mosaic and light mosaic were used for those ears in which a considerable portion of the seeds were striped with deep red. The number and width of these stripes determined the class in which ears were placed. The class, few seeds striped, consisted of ears in which from $I$ to 50 seeds had a few stripes of deep red on the pericarp. The class, very slight pattern, consisted of ears which showed no deep red stripes on the pericarp, but which nevertheless seemed to have a slight color in the pericarp. Microscopical examination showed some reddish coloration in a portion of the cells while other pericarp cells appeared to have no coloring matter. The colorless class consisted of ears in which there appeared to be no color in the pericarp.

It is realized that in a number of these classes no sharp distinction exists. For example the classes deep mosaic, medium mosaic and light mosaic grade into each other. There is also some difficulty in separating the classes, very slight pattern, and colorless. Those ears in which this 


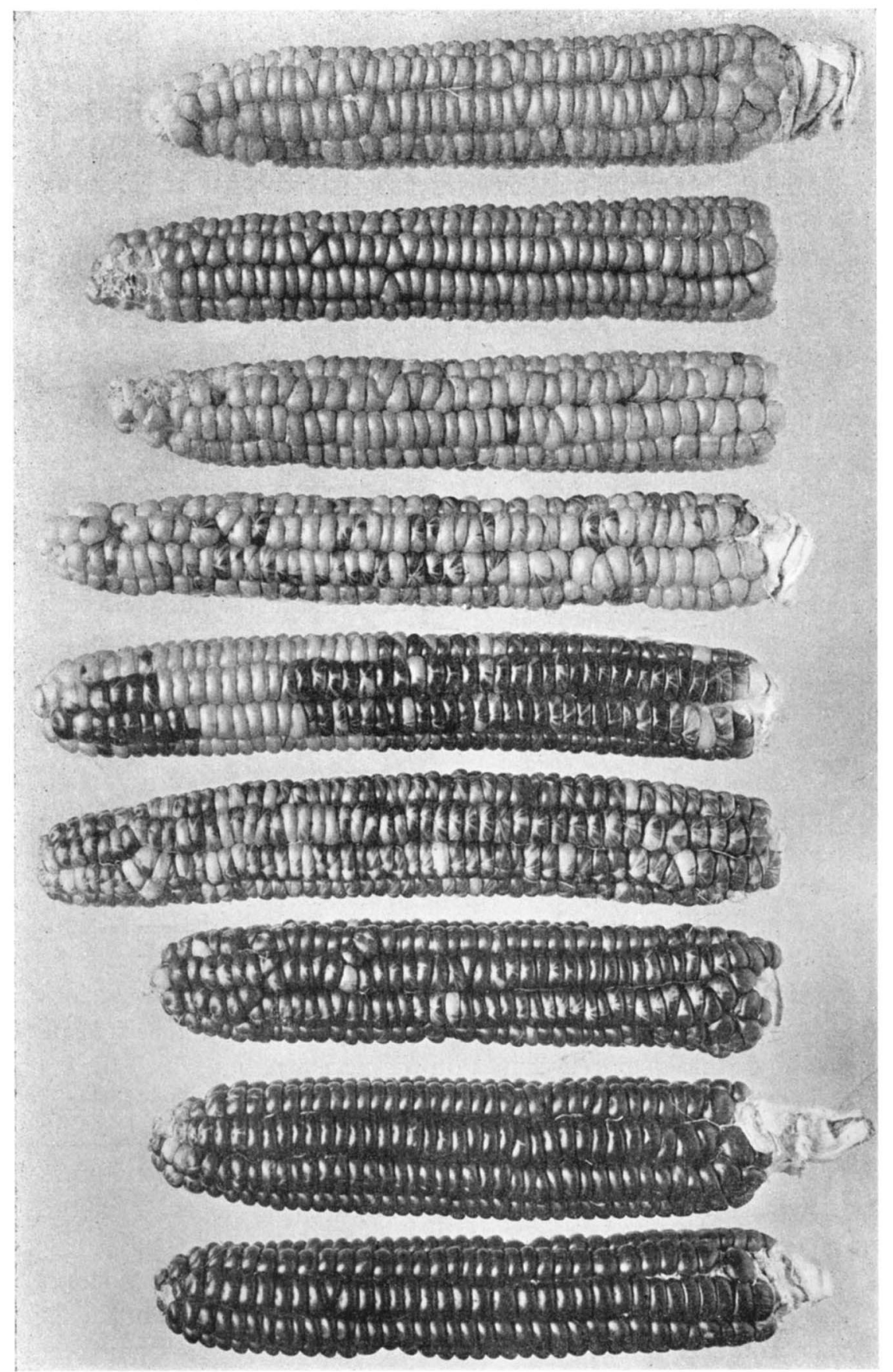

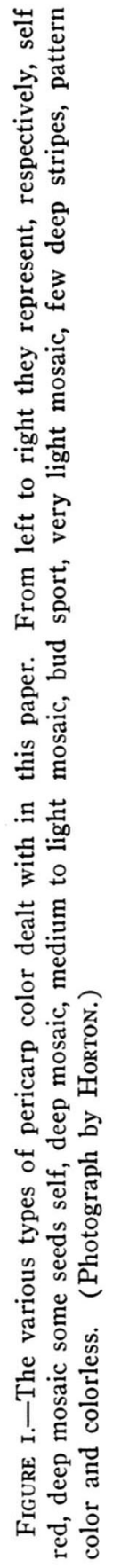


TABLE I. Results obtained for pericarp color from self-fertilized ears of Brindle Flint maize

\begin{tabular}{|c|c|c|c|c|c|c|c|c|c|c|c|c|}
\hline \multirow[b]{2}{*}{ Ear No. } & \multirow[b]{2}{*}{$\begin{array}{l}\text { No.gen. } \\
\text { seifed }\end{array}$} & \multicolumn{9}{|c|}{ Progeny classes for color of pericarp } & \multicolumn{2}{|c|}{ Bud sport } \\
\hline & & $\begin{array}{c}\text { Type of } \\
\text { parent ear }\end{array}$ & $\begin{array}{l}\text { Self } \\
\text { red }\end{array}$ & $\left|\begin{array}{c}\text { Deep mosaic } \\
\text { some } \\
\text { seeds self }\end{array}\right|$ & $\begin{array}{l}\text { Deep } \\
\text { mosaic }\end{array}$ & $\begin{array}{c}\text { Medium } \\
\text { mosaic }\end{array}$ & $\begin{array}{c}\text { Light } \\
\text { mosaic }\end{array}$ & $\begin{array}{c}\text { Few } \\
\text { seeds } \\
\text { striped }\end{array}$ & $\left|\begin{array}{c}\text { Very } \\
\text { slight } \\
\text { pattern }\end{array}\right| C$ & Colorless & $\begin{array}{l}\text { Medium } \\
- \text { light } \\
\end{array}$ & $\begin{array}{l}\text { Medium } \\
\text {-few } \\
\text { stripes }\end{array}$ \\
\hline $\begin{array}{l}(69 \\
(69-6) \\
(69-5)\end{array}$ & I & $\begin{array}{l}\text { Deep mosaic } \\
\text { Medium mosaic }\end{array}$ & & $\begin{array}{c}20 \text { dark and } \\
\text { light } \\
\text { mosaic } \\
74 \text { dark mo- } \\
\text { saic }\end{array}$ & $3^{8}$ mosaic & & \multicolumn{2}{|c|}{$\begin{array}{l}20 \text { non-mosaic } \\
13 \text { non-mosaic }\end{array}$} & (pericarp & \multicolumn{3}{|c|}{$\begin{array}{l}\text { rp pattern and colorless) } \\
\text { rp pattern and colorless) }\end{array}$} \\
\hline $\begin{array}{l}(69-6)-4 \\
(69-6)-4-2 \\
(69-6)-4-2-6 \\
(69-6)-4-2-6-8 \\
(69-6)-4-2-6-8-5 \\
(69-6)-4-2-6-8-2 \\
(69-6)-4-2-6-8-2-7\end{array}$ & $\begin{array}{l}2 \\
3 \\
4 \\
5 \\
6 \\
6 \\
7\end{array}$ & $\begin{array}{l}\text { Deep mosaic } \\
\text { Deep mosaic } \\
\text { Medium mosaic } \\
\text { Medium mosaic } \\
\text { Medium mosaic } \\
\text { Pattern } \\
\text { Pattern }\end{array}$ & 2 & $\begin{array}{r}\text { II } \\
4 \\
8\end{array}$ & $\begin{array}{r}11 \\
6 \\
6 \\
4 \\
\\
\\
5\end{array}$ & $\begin{array}{l}24 \\
25 \\
32 \\
18 \\
17 \\
5\end{array}$ & $\begin{array}{r}6 \\
10 \\
1 \\
4 \\
1\end{array}$ & 2 & \begin{tabular}{l|l}
16 & 23 \\
14 & 3 \\
13 & \\
4 & \\
20 & \\
23 &
\end{tabular} & 3 & $\begin{array}{l}2 \\
1\end{array}$ & \\
\hline $\begin{array}{l}(69-6)-4-1 \\
(69-6)-4-1-6 \\
(69-6)-4-1-6-2 \\
(96-6)-4-1-6-8 \\
\end{array}$ & $\begin{array}{l}3 \\
4 \\
5 \\
5 \\
\end{array}$ & $\begin{array}{l}\text { Pattern } \\
\text { Pattern } \\
\text { Pattern } \\
\text { Pattern } \\
\end{array}$ & & & & & & I & $\begin{array}{l}72 \\
67 \\
35 \\
45 \\
\end{array}$ & & & \\
\hline $\begin{array}{l}(69-6)-5 \\
(69-6)-5-7 \\
(69-6)-5-7-5 \\
(69-6)-5-7-5-6 \\
(69-6)-5-7-5-6-4\end{array}$ & $\begin{array}{l}2 \\
3 \\
4 \\
5 \\
6 \\
\end{array}$ & $\begin{array}{l}\text { Medium mosaic } \\
\text { Deep mosaic } \\
\text { Medium mosaic } \\
\text { Medium mosaic } \\
\text { Medium mosaic }\end{array}$ & $\begin{array}{r}9 \\
13 \\
17 \\
7\end{array}$ & I & $\begin{array}{r}19 \\
11 \\
5 \\
6\end{array}$ & $\begin{aligned} 28 \\
19 \\
11 \\
8 \\
\end{aligned}$ & $\begin{array}{l}4 \\
7 \\
4 \\
1 \\
\end{array}$ & $\begin{array}{r}10 \\
2 \\
13 \\
13\end{array}$ & & & & \\
\hline $\begin{array}{l}(69-6)-5-6 \\
(69-6)-56-7 \\
(69-6)-5-6-7-2\end{array}$ & $\begin{array}{l}3 \\
4 \\
5\end{array}$ & $\begin{array}{l}\text { Few stripes } \\
\text { Few stripes } \\
\text { Light mosaic }\end{array}$ & & & 2 & $\begin{array}{l}1 \\
6 \\
3\end{array}$ & $\begin{array}{l}24 \\
16 \\
24\end{array}$ & $\begin{array}{l}34 \\
19\end{array}$ & & & & \\
\hline $\begin{array}{l}(69-6)-8 \\
(69-6)-9\end{array}$ & $\begin{array}{l}2 \\
2\end{array}$ & $\begin{array}{l}\text { Medium mosaic } \\
\text { Deep mosaic }\end{array}$ & & & & $\begin{array}{l}20 \\
51 \\
\end{array}$ & I & $\begin{array}{l}1 \\
7\end{array}$ & 3 & 3 & & \\
\hline $\begin{array}{l}(69-6)-10 \\
(69-6)-10-1 \\
(69-6)-10-1-5 \\
(69-6)-10-1-5-1 \\
(69-6)-10-1-5-1-13 \\
(69-6)-10-1-5-1-2\end{array}$ & $\begin{array}{l}2 \\
3 \\
4 \\
5 \\
6 \\
6\end{array}$ & $\begin{array}{l}\text { Light mosaic } \\
\text { Deep mosaic } \\
\text { some seeds self } \\
\text { Self red } \\
\text { Self red } \\
\text { Self red } \\
\text { Self red } \\
\end{array}$ & $\begin{array}{r}7 \\
36 \\
47 \\
63 \\
13 \\
\end{array}$ & $\begin{array}{r}19 \\
25 \\
4\end{array}$ & I & $\begin{array}{r}34 \\
8\end{array}$ & & 1 & & & & \\
\hline $\begin{array}{l}(69-6)-10-6 \\
(69-6)-10-6-4 \\
(69-6)-10-6-4-1 \\
(69-6)-10-6-4-1-11 \\
(69-6)-10-6-4-5 \\
(69-6)-10-6-4-5-7\end{array}$ & $\begin{array}{l}3 \\
4 \\
5 \\
6 \\
5 \\
6\end{array}$ & $\begin{array}{l}\text { Deep mosaic } \\
\text { Self red } \\
\text { Self red } \\
\text { Self red } \\
\text { Self red } \\
\text { Self red } \\
\end{array}$ & $\begin{array}{r}7 \\
35 \\
27 \\
48 \\
25 \\
14 \\
\end{array}$ & 25 & & 8 & & & & & & \\
\hline $\begin{array}{l}(69-6)-12 \\
(69-6)-13 \\
(69-6)-16\end{array}$ & $\begin{array}{l}2 \\
2 \\
2\end{array}$ & $\begin{array}{l}\text { Medium mosaic } \\
\text { Medium mosaic } \\
\text { Medium mosaic } \\
\end{array}$ & & & 30 & $\begin{array}{l}18 \\
12 \\
\end{array}$ & 18 & $\begin{array}{l}8 \\
2\end{array}$ & $\begin{array}{ll}3 & 14 \\
2 \\
3 \\
\end{array}$ & & & \\
\hline $\begin{array}{l}69-6)-14-3 \\
(69-6)-14-3-1 \\
(69-6)-14-3^{-2} \\
(69-6)-14-3-3 \\
(69-6)-14-3-5 \\
\end{array}$ & $\begin{array}{l}3 \\
4 \\
4 \\
4 \\
4 \\
\end{array}$ & $\begin{array}{l}\text { Self red } \\
\text { Self red } \\
\text { Self red } \\
\text { Self red } \\
\text { Self red }\end{array}$ & $\begin{array}{l}52 \\
36 \\
55 \\
62 \\
54 \\
\end{array}$ & $\begin{array}{r}6 \\
5 \\
4 \\
11\end{array}$ & $\begin{array}{l}3 \\
3 \\
1\end{array}$ & & & & & & & \\
\hline $\begin{array}{l}\overline{(6-6)-14-4} \\
(69-6)-14-4-6 \\
(69-6)-14-4-6-1\end{array}$ & $\begin{array}{l}3 \\
4 \\
5\end{array}$ & $\begin{array}{l}\text { Medium mosaic } \\
\text { Medium lig h } \\
\text { mosaic } \\
\text { Few stripes }\end{array}$ & 1 & 7 & 5 & 5 & $\begin{array}{l}\mathbf{8} \\
9 \\
\mathbf{3}\end{array}$ & $\begin{array}{l}22 \\
27\end{array}$ & 2 & & & \\
\hline $\begin{array}{l}(69-6)-14-5 \\
(69-6)-14-5-6 \\
(69-6)-14-5-6-8 \\
(69-6)-14-5-6-8-6 \\
(69-6)-14-5-6-86-1 \\
\end{array}$ & $\begin{array}{l}3 \\
4 \\
5 \\
6 \\
7\end{array}$ & $\begin{array}{l}\text { Medium mosaic } \\
\text { Medium mosaic } \\
\text { Deep mosaic } \\
\text { some seeds self } \\
\text { Self red } \\
\text { Self red } \\
\end{array}$ & $\begin{array}{l}20 \\
22 \\
73 \\
73 \\
\end{array}$ & $\begin{array}{r}5 \\
20 \\
1\end{array}$ & $\begin{array}{r}11 \\
6\end{array}$ & $\begin{array}{r}32 \\
38 \\
7\end{array}$ & ${ }^{12}$ & 2 & 6 & & & \\
\hline $\begin{array}{l}(69-6)-17 \\
(69-6)-17-3 \\
(69-6)-17-8 \\
(69-6)-17-8-3 \\
(69-6)-17-8-3-4 \\
(69-6)-17-8-3-4-8 \\
(69-6)-17-8-3-4-8-7 \\
(69-6)-17-8-3-4-7 \\
(69-6)-17-8-3-4-7-5 \\
\end{array}$ & $\begin{array}{l}2 \\
3 \\
3 \\
4 \\
4 \\
5 \\
6 \\
7 \\
6 \\
7 \\
\end{array}$ & \begin{tabular}{|c|} 
Medium mosaic \\
Deep mosaic \\
Medium a n d \\
deep mosaic \\
Deep mosaic \\
Medium a n d \\
deep mosaic \\
Medium mosaic \\
Medum mosaic \\
Medium mosaic \\
Medium mosaic \\
\end{tabular} & $\begin{array}{l}1 \\
8 \\
2\end{array}$ & $\begin{array}{l}7 \\
4\end{array}$ & $\begin{array}{r}10 \\
17 \\
11 \\
6 \\
5 \\
9 \\
9\end{array}$ & $\begin{array}{r}12 \\
4 \\
23 \\
22 \\
23 \\
33 \\
20 \\
4 \\
23 \\
6\end{array}$ & $\begin{array}{l}7 \\
12 \\
1 \\
6 \\
5 \\
3\end{array}$ & $\begin{array}{r}13 \\
29 \\
4 \\
5 \\
4 \\
1 \\
3 \\
3\end{array}$ & & & 6 & 2 \\
\hline $\begin{array}{l}(69-6)-17-8-4 \\
(69-6)-17-8-4-7\end{array}$ & $\begin{array}{l}4 \\
5\end{array}$ & $\begin{array}{l}\text { Few stripes } \\
\text { Few stripes }\end{array}$ & & & & 4 & 20 & $\begin{array}{l}37 \\
20\end{array}$ & & & & $\begin{array}{l}2 \\
1\end{array}$ \\
\hline $\begin{array}{l}(69-6)-17-8-3-4-2 \\
(69-6)-17-8-3-4-2-4 \\
(69-6)-17-8-3-4-2-5 \\
\end{array}$ & $\begin{array}{l}6 \\
7 \\
7\end{array}$ & $\begin{array}{l}\text { Medium mosaic } \\
\text { Medium mosaic } \\
\text { Few stripes }\end{array}$ & & & $\begin{array}{l}6 \\
1 \\
\end{array}$ & $\begin{array}{r}35 \\
3 \\
1 \\
\end{array}$ & 7 & $\begin{array}{l}8 \\
7 \\
1\end{array}$ & $\begin{array}{r}12 \\
7 \\
1 \\
\end{array}$ & & & \\
\hline \begin{tabular}{l|}
$(69-6)-18-8$ \\
$(69-6)-18-8-3$ \\
$(69-6)-18-8-3-2$ \\
$(69-6)-18-8-3-2-10$ \\
$(69-6)-18-8-3-2-2$ \\
$(69-6)-18-8-3^{-2-10-1}$ \\
$(69-6)-18-8-3-2-10-2$ \\
\end{tabular} & $\begin{array}{l}3 \\
4 \\
5 \\
6 \\
6 \\
7 \\
7 \\
\end{array}$ & $\begin{array}{l}\text { Medium mosaie } \\
\text { Medium mosaic } \\
\text { Medium mosaic } \\
\text { Light mosaic } \\
\text { Light mosaic } \\
\text { Few stripes } \\
\text { Light mosaic } \\
\end{array}$ & & & 3 & $\begin{array}{r}22 \\
22 \\
18 \\
26 \\
10 \\
2 \\
2\end{array}$ & $\begin{array}{r}2 \\
30 \\
3 \\
20 \\
1 \\
17 \\
\end{array}$ & $\begin{array}{l}5 \\
6 \\
3 \\
3 \\
5 \\
1 \\
5 \\
5\end{array}$ & $\begin{array}{l}3 \\
7 \\
6 \\
2\end{array}$ & & & 2 \\
\hline $\begin{array}{l}(69-5)-1 \\
(69-5)-1-2 \\
(69-5)-1-2-2 \\
(69-5)-1-2-2-8 \\
(69-5)-1-2-2-8-6 \\
(69-5)-1-2-2-8-6-5\end{array}$ & $\begin{array}{l}2 \\
3 \\
4 \\
5 \\
6 \\
7\end{array}$ & $\begin{array}{l}\text { Medium mosaic } \\
\text { Medium mosaic } \\
\text { Medium mosaic } \\
\text { Medium mosaic } \\
\text { Medium mosaic } \\
\text { Medium mosaic }\end{array}$ & I & I & $\begin{array}{r}11 \\
5 \\
3\end{array}$ & $\begin{array}{r}18 \\
75 \\
30 \\
18 \\
6 \\
3\end{array}$ & $\begin{array}{r}3 \\
2 \\
12 \\
5\end{array}$ & $\begin{array}{r}21 \\
11 \\
1 \\
2 \\
1\end{array}$ & I & 3 & & \\
\hline $\begin{array}{l}(69-5)-2 \\
(69-5)-3\end{array}$ & $\begin{array}{l}2 \\
2 \\
\end{array}$ & $\begin{array}{l}\text { Medium mosaic } \\
\text { Medium mosaic }\end{array}$ & & & $4 \mathrm{I}$ & 40 & $\begin{array}{l}5 \\
3\end{array}$ & 3 & & I & & \\
\hline $\begin{array}{l}(69-5)-8 \\
(69-5)-8-3 \\
(69-5)-8-3-5 \\
(69-5)-8-3-5-5 \\
(69-5)-8-3-5-2 \\
(6 g-5)-83-5-2-8 \\
(69-5)-8-3-5-2-7 \\
(69-5)-8-3-5-5-2-8 \\
\end{array}$ & $\begin{array}{l}2 \\
3 \\
4 \\
5 \\
5 \\
5 \\
6 \\
6 \\
\end{array}$ & $\begin{array}{l}\text { Light mosaic } \\
\text { Colorless } \\
\text { Colorless } \\
\text { Colorless } \\
\text { Colorless } \\
\text { Colorless } \\
\text { Colorless } \\
\text { Possibly pattern } \\
\end{array}$ & & & . & II & 12 & $\begin{array}{l}4 \\
4\end{array}$ & \begin{tabular}{l|l}
2 & 5 \\
2 & 9 \\
$=$ & \\
& 9
\end{tabular} & \begin{tabular}{|rr}
5 & 1 \\
1 & 51 \\
9 & 20 \\
& 33 \\
& 30 \\
29 \\
45 \\
\\
25 \\
\end{tabular} & & \\
\hline 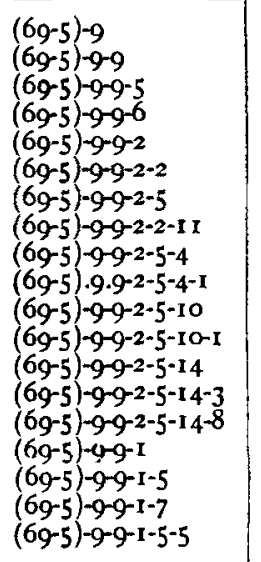 & $\begin{array}{l}2 \\
3 \\
4 \\
4 \\
4 \\
5 \\
5 \\
6 \\
6 \\
7 \\
6 \\
7 \\
6 \\
7 \\
7 \\
4 \\
5 \\
5\end{array}$ & $\begin{array}{l}\text { Light mosaic } \\
\text { Light mosaic } \\
\text { Light mosaic } \\
\text { Light mosaic } \\
\text { Light mosaic } \\
\text { Few stripes } \\
\text { Medium to light } \\
\text { Few stripes } \\
\text { Light mosaic } \\
\text { Medium mosaic } \\
\text { Medium mosaic } \\
\text { Medium mosaic } \\
\text { Light mosaic } \\
\text { Medium mosaic } \\
\text { Medium mosaic } \\
\text { Few stripes } \\
\text { Medium mosaic } \\
\text { Few stripes } \\
\text { Medium mosaic }\end{array}$ & & & & $\begin{array}{r}12 \\
4 \\
6 \\
6 \\
3^{6} \\
1 \\
1 \\
2 \\
2 \\
4 \\
2 \\
3 \\
1 \\
8 \\
14 \\
16\end{array}$ & $\begin{array}{r}36 \\
50 \\
51 \\
34 \\
44 \\
8 \\
5 \\
25 \\
46 \\
5 \\
46 \\
20 \\
32 \\
22 \\
12 \\
35 \\
36 \\
7 \\
17\end{array}$ & $\begin{array}{r}7 \\
30 \\
6 \\
3 \\
11 \\
28 \\
13 \\
7 \\
6 \\
2 \\
3 \\
2 \\
12 \\
2 \\
15 \\
15 \\
31 \\
3\end{array}$ & & & & \\
\hline
\end{tabular}


seemed impossible are placed half way between the two class headings in this table.

While it is possible that some variation may occur, due to a changing ideal as to the value of a particular class, the classification given serves its purpose as it differentiates between heavily striped ears and ears in which the seeds are less heavily splashed with red striations.

The classes self red, deep mosaic some seeds self, and few seeds striped, are of a more distinct type and present little difficulty as regards uniform classification.

Table I gives the results obtained from the self-fertilized ears, the progeny of each ear being given separately. Column I under Ear No. gives the pedigree of the ears grown, column 2 gives the number of generations that the particular line has been self-fertilized, column 3 gives the type of pericarp of the parental ear. while the remaining columns show the range of variation and classification of the progeny of any particular ear.

In a consideration of the results obtained, each pedigree line will be separately discussed.

The progeny for the first two years were not very carefully classified. Beginning with the second generation there is, however, a uniform classification.

The results obtained show a general degree of uniformity for the various types of self-fertilized ears grown. We shall first discuss the families grown from self-fertilized self red pericarp ears.

Family (69-6)-I0-6-4 gave a progeny of 35 red ears. Two selections of later generations showed a total progeny of I 4 ears all of which had a self red pericarp. The fourth generation selection of family (69-6)IO-I-5 was grown from a self-fertilized self red ear and gave 36 self red ears and 4 in the deep mosaic some seeds self class. As none of the four variegated ears were self-fertilized it was impossible to determine whether they were somatic or germinal variations from the self red type.

One fifth generation and two sixth generation selections gave a total of 123 self red pericarp ears. One third generation family (69-6)-I 4-3 and three fourth generation lines grown from self-fertilized self red pericarp ears gave a total progeny of 205 self red ears, 26 deep mosaic some seeds self and 7 deep mosaic. One fifth generation family gave a progeny of 54 self red ears.

The sixth and seventh generations of family (69-6)-14-5-6-8-6 gave a total of 146 self red ears and I deep mosaic some seeds self ear. In 
no case has it been possible to test by breeding experiments the nature of the few deep mosaic ears obtained from self red parentage.

The results given show that the self red ears obtained from variegated parentage tend to give self red progeny. In two families, (69-6)-10-6-4 and (69-6)-IO-I-5-I, a total progeny of 233 self red pericarp ears were obtained with no ears in the variegated class.

Two self-fertilized ears of the deep mosaic some seeds self class, (696) I 4-5-6-8 and (69-6)-IO-I, behaved as if hybrids between homozygous variegated and pure self red parents, giving a total of 29 self red ears, 45 deep mosaic some seeds self, 6 deep mosaic, I 5 medium mosaic, I light mosaic, or a total of 67 variegated to 29 self red ears.

This is a ratio per 4 of $2.792: 1.208$. The probable error for this ratio as computed by EAST and Hayes (I9II) is \pm O.I43. This is, therefore, a fairly close approximation to a 3 : I ratio.

The progeny of self-fertilized deep and medium mosaic ears can be placed in four groups: Group $\mathrm{I}$, in which the progeny ranges from self red ears to ears with a few seeds striped, the proportion of self red ears being about one-third of the total progeny; Group 2, in which the progeny show only a few isolated cases of the production of self red ears, the remainder being variegated ears; Group 3, in which the range of variation is from self red ears to ears with a very slight pattern; Group 4, which gives ears ranging from medium mosaic to the few seeds striped class.

Group $I$ is represented by the progeny of $(69-6)-5,4$ other selections of later generations of this line, $(69-6)-10-6$ and $(69-6)-14-5-6$. The total progeny of these self-fertilized parental ears is as follows: 73 self red ears, $3^{1}$ deep mosaic some seeds self, $5^{2}$ deep mosaic, I05 medium mosaic, 28 light mosaic and $3^{8}$ few seeds striped. This makes a total of 254 variegated to 73 self red ears or a ratio per 4 of $3.107: 0.893$. The deviation from a $3:$ I ratio is 0.107 and the computed probable error \pm 0.065 .

Of the variegated ears I 3 percent were placed in the deep mosaic some seeds self class and 20 percent in the deep mosaic class. The variegated ears, obtained from self-fertilized deep mosaic some seeds self parental ears previously mentioned, gave 67 percent of the variegated ears in the deep mosaic some seeds self class and 9 percent in the deep mosaic class. These results show that self-fertilized ears of the deep mosaic some seeds self type give a larger percentage of deep mosaic some seeds self ears than is obtained from self-fertilized deep or medium mosaic ears.

Group 2 consists of family (69-5) -I and five selections of later gener- 
ations. The progeny consisted of the following ears:- I self red, I deep mosaic some seeds self, I9 deep mosaic, I50 medium mosaic, 22 light mosaic, 36 few seeds striped and 1 very slight pattern and 3 either colorless or very slight pattern.

Disregarding the very slight pattern ears, the proportion of self red ears to variegated is in the ratio of $\mathrm{I}$ to 77.3 . It is possible that ear (69-6) -I 8-8-3 also belongs to this group, although 7 ears were classified as very slight pattern.

Group 3 may be represented by family (69-6)-4 and four selections of later generations. The progeny of these self-fertilized deep and medium mosaic ears consisted of ears as follows:-2 self red, 23 deep mosaic some seeds self, 27 deep mosaic, I 6 medium mosaic, 2 I light mosaic, 6 few seeds striped, 47 very slight pattern and 23 which were classed as either very slight pattern or colorless.

Considering the doubtful ears as belonging to the very slight pattern class there is a ratio per 4 of very slight pattern to variegated and self red pericarp ears of $1.057: 2.943$. The deviation from a $\mathrm{I}: 3$ ratio is 0.057 and the probable error \pm 0.072 .

Group 4 may be represented by some generations in family (69-5) -9 in which the range of variation of the progeny consists of the three classes medium mosaic, light mosaic and few seeds striped.

Family (69-5)-9 and later generations consist of a progeny of $\mathrm{I} 8 \mathrm{I}$ few seeds striped ears, 53 I light mosaic ears and I 2 medium mosaic ears. As no ears of a higher grade than medium mosaic or a lower grade than few seeds striped were obtained it will be noted that this family is homozygous for variegation.

The question at once suggests itself: Do self-fertilized ears of the few seeds striped class give a larger proportion of progeny of this grade than self-fertilized medium mosaic ears? As a means of answering this question table 2 has been prepared from the data given in table I. The percentage of ears of the different grades, medium mosaic, light mosaic and few seeds striped, is given in the table. In discussing these results it should be stated that there is no sharp border line between these different classes. The class few seeds striped is, however, of a more definite type than the other two classes.

A careful study of table 2 shows that self-fertilized medium or light mosaic ears give a smaller percentage of few seeds striped progeny than is obtained from self-fertilized few seeds striped ears. As neither grade, medium mosaic nor few seeds striped, breeds true, and as no definite 
TABLE 2

Selection experiments within family (69-5)-9 which bred true for a range of variation from medium mosaic ears to ears with a few seeds striped.

\begin{tabular}{|c|c|c|c|c|c|}
\hline \multirow[b]{2}{*}{ Parentage } & \multirow[b]{2}{*}{ Generation } & \multirow[b]{2}{*}{$\begin{array}{l}\text { Type of } \\
\text { parent ear }\end{array}$} & \multicolumn{3}{|c|}{ Proge $n y$} \\
\hline & & & $\begin{array}{c}\text { Percent of } \\
\text { medium } \\
\text { mosaic ears }\end{array}$ & $\begin{array}{l}\text { Percent of } \\
\text { light } \\
\text { mosaic ears }\end{array}$ & $\begin{array}{l}\text { Percent of } \\
\text { few seeds } \\
\text { striped ears }\end{array}$ \\
\hline $\begin{array}{l}69-5-9-9-5 \\
69-5-9-9-6 \\
69-5-9-9-2 \\
69-5-9-9-1\end{array}$ & 4 & $\begin{array}{l}\text { Light mosaic } \\
\text { Light mosaic } \\
\text { Light mosaic } \\
\text { Few seeds striped }\end{array}$ & $\begin{array}{r}2 \mathrm{I} \\
\text { I0 } \\
0 \\
2\end{array}$ & $\begin{array}{l}71 \\
83 \\
80 \\
60\end{array}$ & $\begin{array}{r}8 \\
7 \\
20 \\
29\end{array}$ \\
\hline $\begin{array}{l}69-5-9-9-2-5 \\
69-5-9-9-2-2 \\
69-5-9-9-1-5 \\
69-5-9-9-1-7\end{array}$ & 5 & $\begin{array}{l}\text { Medium to light } \\
\text { Few seeds striped } \\
\text { Medium mosaic } \\
\text { Few stripes }\end{array}$ & $\begin{array}{l}66 \\
19 \\
18 \\
27\end{array}$ & $\begin{array}{r}9 \\
25 \\
82 \\
13\end{array}$ & $\begin{array}{l}25 \\
56 \\
60\end{array}$ \\
\hline $\begin{array}{l}69-5-9-9-1-5-5 \\
69-5-9-9-2-5-10 \\
69-5-9-9-2-5-14 \\
69-5-9-9-2-5-4 \\
69-5-9-9-2-2-11\end{array}$ & 6 & $\begin{array}{l}\text { Medium mosaic } \\
\text { Medium mosaic } \\
\text { Light mosaic } \\
\text { Light mosaic } \\
\text { Few stripes }\end{array}$ & $\begin{array}{r}44 \\
4 \\
\text { I I } \\
- \\
-\end{array}$ & $\begin{array}{l}48 \\
90 \\
89 \\
88 \\
79\end{array}$ & $\begin{array}{r}8 \\
6 \\
0 \\
12 \\
21\end{array}$ \\
\hline $\begin{array}{l}69-5-9-9-2-5-10-1 \\
69-5-9-9-2-5-14-3\end{array}$ & 7 & $\begin{array}{l}\text { Medium mosaic } \\
\text { Medium mosaic }\end{array}$ & $\begin{array}{l}8 \\
6\end{array}$ & $\begin{array}{l}84 \\
6 \mathrm{I}\end{array}$ & $\begin{array}{r}8 \\
33\end{array}$ \\
\hline
\end{tabular}

ratios are obtained, these results do not appear to be of the usual Mendelian type of segregation.

Self-fertilized ears of the very slight pattern type are represented by ear No. (69-6)-4-2-6-8-2, one selection of a later generation, ear No. $(69-6)-4$-I and three selections of later generations. In one case ear No. $(69-6)-4-2-6-8-2-7$ a considerable percentage of variegated ears were obtained. These may possibly be due to accidental causes. The other selffertilized ears gave a total progeny of 240 ears of which 239 were of the very slight pattern type, while I showed a single deep red stripe on one seed.

It seems reasonable to conclude, therefore, that ears can be isolated which are homozygous for slight pattern. There is, however, the possibility of a gradual cumulative effect and thus the production of an occasional ear of a higher grade of variegation.

Family (69-5)-8-3 and six selections of later generations consisted of self-fertilized colorless pericarp ears. Four ears of the very slight pattern type, 7 of the light mosaic and few seeds striped class, and 263 
colorless pericarp ears were obtained. As none of the variegated ears were seffed it is impossible to say how they would breed.

\section{RESULTS OF SELECTION EXPERIMENTS}

I. Selection experiments with a mosaic pericarp pattern color of corn have isolated the following types which breed comparatively true:

(a) A self red pericarp;

(b) Pure for variegation but giving a range of variability from ears with only a few seeds with deep red stripes to ears in which nearly all seeds are quite heavily covered with red striations;

(c) A type with a very slight pattern color which under the microscope appears to be due to the presence of a faint color in some of the pericarp cells;

(d) An uncolored pericarp race.

2. Selection within type (b) which breeds true for variegation has not succeeded in isolating strains which breed true for amount of variegation. Extreme minus types within this strain tend to give a progeny containing more ears of the minus type than are obtained from extreme plus types.

3. Heavily striated self-fertilized ears have proven to be heterozygous, giving a progeny which exhibits segregation for one factor difference.

4. The very deeply variegated heterozygous self-fertilized ears give a progeny in which a greater proportion of the variegated segregates are deeply variegated than is obtained in the progeny of less deeply variegated self-fertilized heterozygous ears.

\section{CROSSES BETWEEN SELECTED TYPES}

After isolating several comparatively pure types by selection it was decided to determine their mode of inheritance and relationship to each other by crosses between these various types. For convenience the various crosses will be considered as families and discussed separately.

Family I. Reciprocal crosses between the self red pericarp type and the homozygous variegated type which exhibited a range of variation from medium mosaic ears to few seeds striped ears

The results from this cross are presented in table 3. Three $F_{1}$ crosses are given in the table, reciprocal crosses giving like results. A total of I 5 deep mosaic and 84 medium mosaic ears were obtained in the $F_{1}$ generation. Five $F_{1}$ self-fertilized ears gave the same sort of segregation in $F_{2}$. A total progeny was obtained of 98 self red ears, 89 deep 


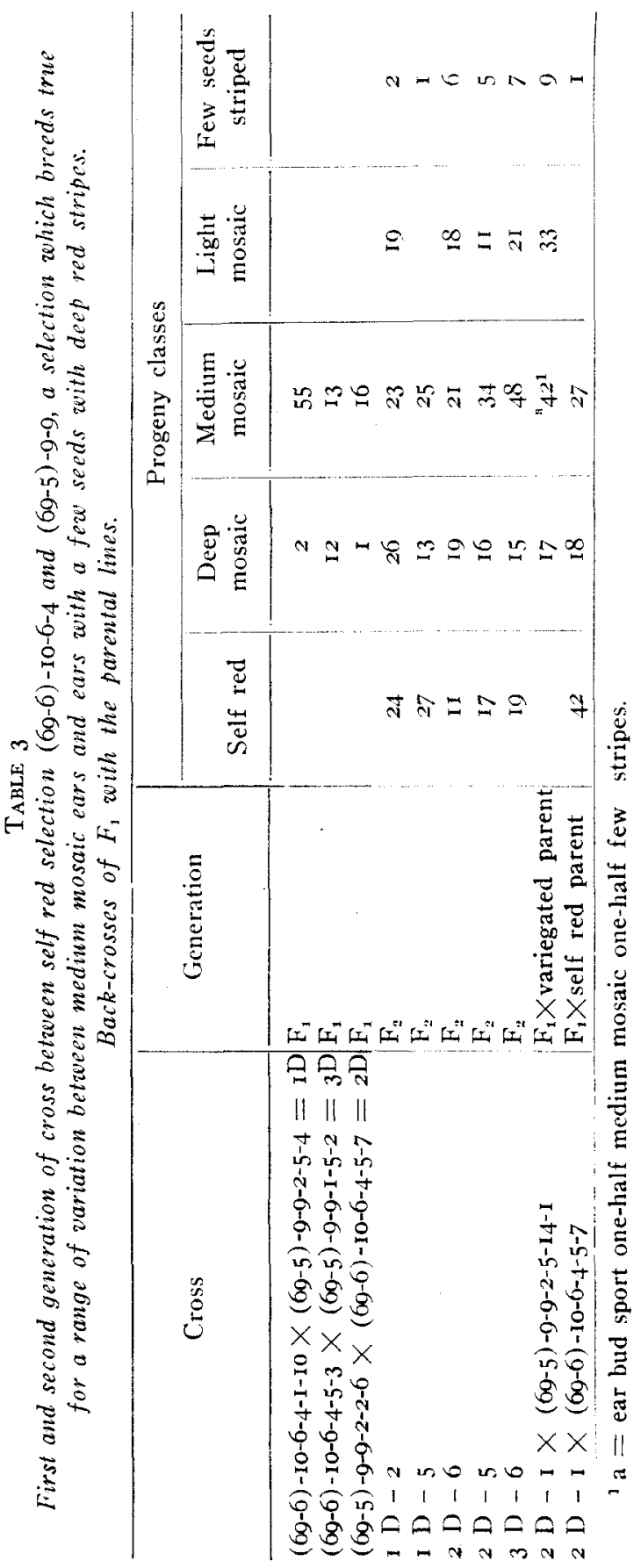


mosaic ears, I5I medium mosaic ears, 69 light mosaic ears and 21 few seeds striped ears. This is a ratio per 4 for variegated to self red of $3.084: 0.916$. The probable error in this case is \pm 0.056 .

One $F_{1}$ generation ear was pollinated by the variegated parent and gave a progeny of $\mathrm{I} 7$ deep mosaic, 4I medium mosaic, 33 light mosaic, 9 few seeds striped, and I bud sport, a part of the ear being medium mosaic, the other part belonging to the few seeds striped type.

The back-cross of the $F_{1}$ with the self red parent gave 42 self red ears, 18 deep mosaic ears and 27 medium mosaic ears.

The results obtained from the $F_{2}$ generation and the crosses of $F_{1}$ with the parental types, respectively, show that one main factor difference is involved. If we consider these factors as $M$ and $S$ respectively, we may conclude that $M$ and $S$ are allelomorphs or according to MorGAN's chromosome hypothesis, located in corresponding loci of homologous chromosomes.

Family 2. First and second generation crosses of homozygous self red pericarp and pattern selections

The same self red races were used as for the cross between self red and homozygous variegated described in the previous family. The $F_{1}$ generation cross of the self red with the pattern selection consisted of self red ears and in $F_{2}$ rog self red ears, 39 pattern ears and I ear with one deep red stripe on one seed was obtained. This is a clear indication of a $3:$ I ratio.

Comparing these results with family I shows a complete dominance of the self red pericarp in one cross and an intermediate condition in the other cross. There is a greater difference in character between the self red and pattern types than for the self red and variegated selections. Complete dominance was obtained in the cross in which the parental varieties differed most widely.

TABLE 4

First and second generation of cross between selection (69-6)-4-I-6-2-7 and (69-6)4-I-6-8-3, which breed true for pattern color, and (69-10)-I-5-I-2 and (69-IO)6-4-5-I, selections which breed true for self red pericarp.

\begin{tabular}{|c|c|c|c|}
\hline \multirow{2}{*}{ Cross } & \multirow{2}{*}{ Generation } & \multicolumn{2}{|c|}{ Progeny classes } \\
\hline & & Self red & Pattern \\
\hline $\begin{array}{l}(69-6)-4-\mathrm{I}-6-2-7 \times(69-10)-\mathrm{I}-5-\mathrm{I}-2=\mathrm{I} \\
(69-6)-4-\mathrm{I}-6-8-3 \times(69-10)-6-4-5-\mathrm{I}=2 \\
\mathrm{I} B-8 \\
2 \mathrm{~B}-\mathrm{I}\end{array}$ & $\begin{array}{l}\mathrm{F}_{1} \\
\mathrm{~F}_{1} \\
\mathrm{~F}_{2} \\
\mathrm{~F}_{2}\end{array}$ & $\begin{array}{c}{ }^{58} \\
\text { All self } \\
53 \\
56\end{array}$ & $\begin{array}{c}{ }^{8} 2 \mathbf{I}^{2} \\
19\end{array}$ \\
\hline
\end{tabular}

$2 \mathrm{a}=$ Deep red stripe on one ear. 
Family 3. First and second generations of the cross between the pattern selection and the variegated type

The parental types are the recessive selections of the crosses given in families I and 2. $M M$ represents the selection which proved to be homozygous for the variegated character. Table I shows a total progeny of 324 ears obtained in family (69-5)-9 all of which were of the variegated type. $P P$ represents the pattern type, $(69-6)-4-I-6$, which bred true to the pattern condition. These two selections when crossed with the self red pericarp type showed the ordinary Mendelian expectation in $F_{2}$ for one factor difference.

The results obtained for the cross between variegated and pattern selections are presented in table 5 .

The $F_{1}$ generation consisted of 143 variegated ears and I ear of the pattern type. Of the variegated ears 5 were classed as deep mosaic which is a higher grade than was obtained in the homozygous variegated parent and 4 were classed as bud sports. As no bud sports appear in either of the homozygous parental varieties, it would seem as if crossing has in some way produced a condition of instability. This instability is also shown by the increased variability obtained in $F_{1}$ from crossing apparently homozygous types.

Nine self-fertilized $F_{1}$ ears were grown in $F_{2}$. Three of these ears were of the bud sport type, while of the other six 5 were classed as light mosaic and one as medium mosaic. The three ears classed as bud sports gave a total progeny of I 88 ears, Io of these being bud sports. The "non-sport" ears gave a total progeny of 445 ears, I I of which were bud sports. The ratio of bud sport ears from self-fertilized bud sport parentage is I bud sport to 18.8 normal. When normal ears were planted I of the bud sport type was obtained to 40.4 ears of the normal type.

The $F_{2}$ generation exhibits a greater variability than the $F_{1}$. Nine $F_{1}$ self-fertilized ears gave a total progeny in $F_{2}$ of 12 self red ears, 420 variegated ears ranging from deep mosaic some seeds self to ears with only a few seeds striped with deep red, 2 I which exhibited sharp segregation of characters on the ear, a part of the ear being of one type, the remainder being of another type and $20 \mathrm{r}$ ears of the pattern type.

This is a total of $20 \mathrm{I}$ pattern ears to 453 of the variegated and self red classes or a ratio per 4 of pattern ears to other sorts of I.229:2.77 I. 


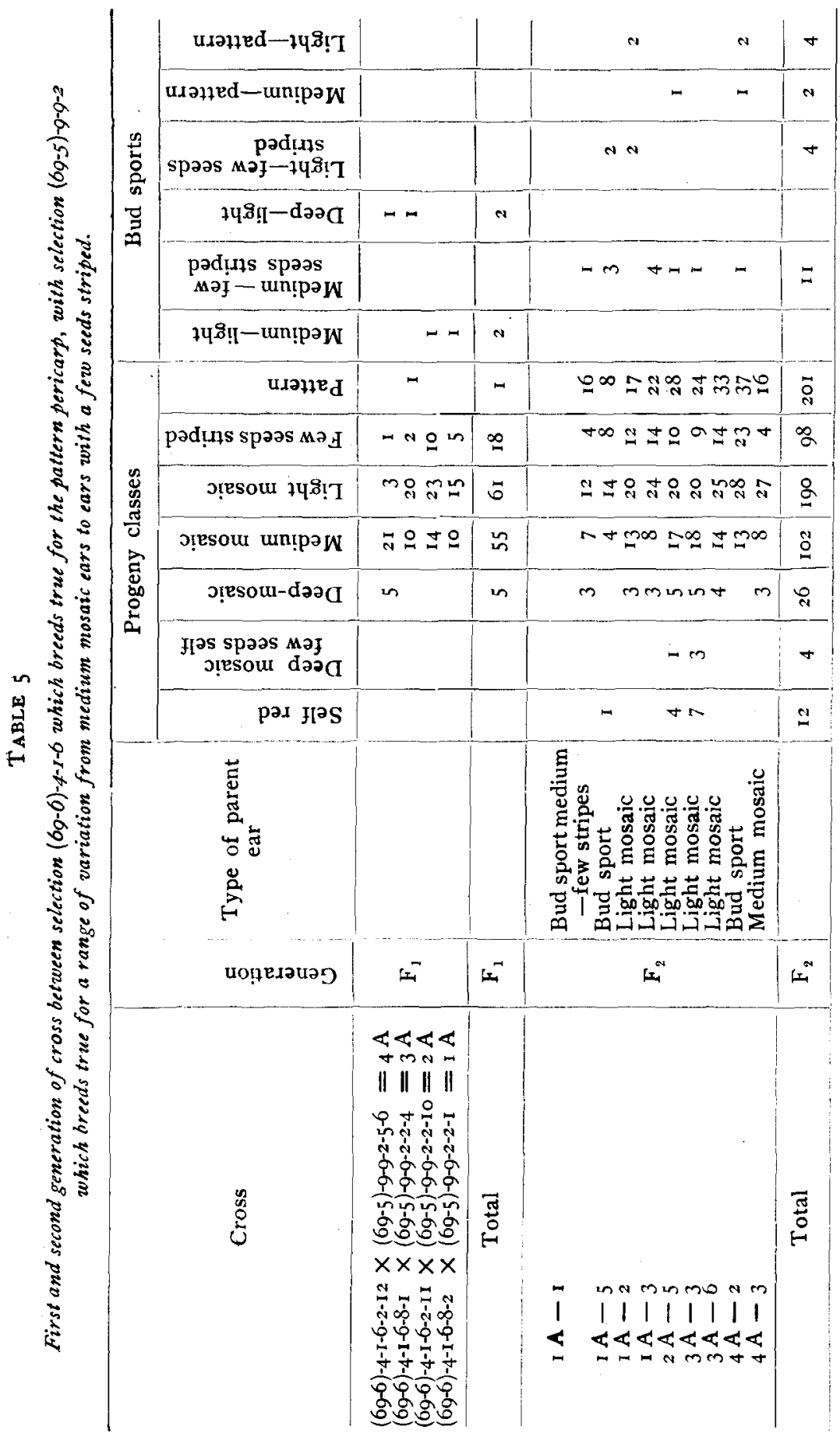


Family 4. First and second generation of cross betaecn the homozygous variegated and colorless selections

The results of this cross are presented in table 6 . The $F_{1}$ generation consisted of $4 \mathrm{I}$ variegated ears. In $\mathrm{F}_{2}$ IO 3 variegated, I 7 pattern, and 28 colorless pericarp ears were obtained. One of the variegated ears was of a higher grade than the $F_{1}$ or variegated pattern type. The nature of these $I 7$ pattern ears could only be determined by breeding test, which was impossible, as none of these ears happened to be selfed.

As only a single cross between variegated and colorless has been studied, it does not seem wise to make an extended discussion of these results. The deviations from simple Mendelian expectations might be explained by supposing the variegated factor $M$ to change to a factor for self color $S$ or to the pattern factor $P$. It is equally possible that these results might be explained by accidental chance pollination.

\section{RESULTS OF CROSSING HOMOZYGOLS TYPES}

I. The cross between the self red selection $S S$ and the homozygous variegated type $M M$ gave an intermediate $\mathrm{F}_{\mathrm{x}}$ which consisted of ears which were more deeply striated than the homozygous variegated race. The $\mathrm{F}_{2}$ generation grown from self-fertilized $\mathrm{F}_{1}$ ears showed a segregation of self red, $F_{1}$, and homozygous types, as expected for one unitfactor difference. Back-crosses of the $F_{1}$ with the parental strains gave parental and $F_{1}$ types in a $I$ : I ratio.

2. The cross between the self red selection $S S$ and the pattern selection $P P$ showed a dominance of the self red type in $F_{1}$ and in $F_{2}$ a segregation of self red and pattern types in a $3:$ I ratio.

3. The cross between the homozygous variegated selection $M M$ and the pattern selection $P P$ gave an increase of variability in $F_{1}$ which was shown by ears of a higher grade for variegation than the parental variegated race and by the production of a considerable proportion of bud sport ears. In $\mathrm{F}_{2}$ some self red ears were obtained. The proportion of pattern ears to other grades was I to 2.3 .

4. The cross between the homozygous variegated race, $M M$, and the colorless race, $C C$, gave $F_{1}$ ears of the variegated type and a segregation in $F_{2}$. One ear of a higher grade than the $F_{1}$ and a number of ears of the pattern type were obtained as well as a considerable number of ears of the two parental types. 


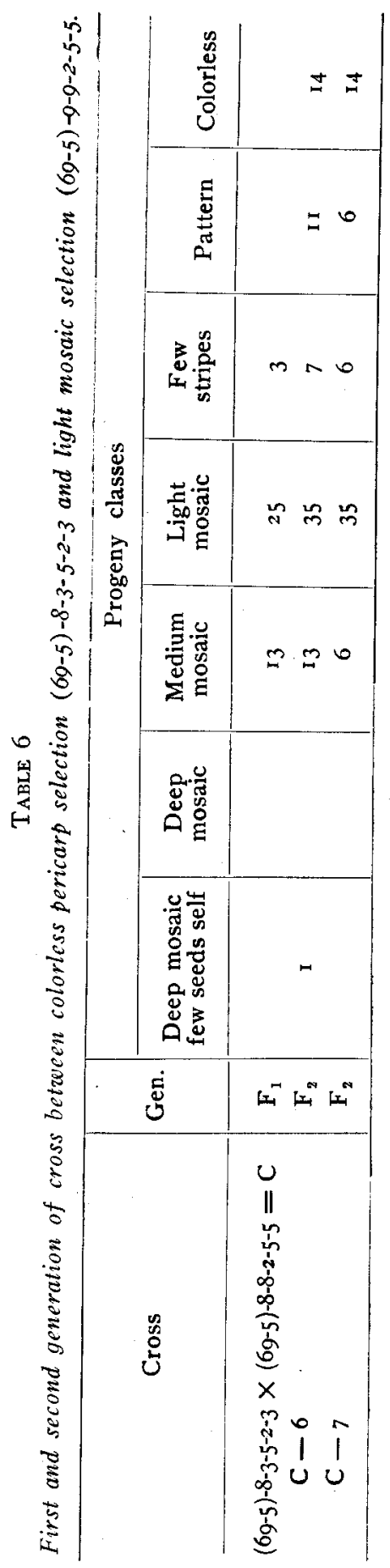


The results presented in the experiments are of two sorts:

I. Those which show the usual type of Mendelian inheritance, i.e., dominance, recessiveness, and segregation with definite ratios.

2. Results which are not easily explained by the hypothesis of absolute purity of fundamental factors of inheritance.

The use of several main factors is helpful in an explanation of the Mendelian results obtained. The letters $S$ and $M$ respectively denote factors for self color and variegation. The letter $P$ may be used to denote the very slight pericarp pattern factor which in the absence of $M$ or $S$ produces a slight pattern color. This appears to be a true pattern factor as a portion of the cells of the pericarp of a homozygous very slight pattern race show a slight color while other cells appear to contain no coloring matter.

Selection experiments served to isolate races which bred comparatively true for the following pericarp characters: Self red, $S S$, homozygous variegated, $M M$, very slight pattern, $P P$, and colorless, $C C$. The crosses between self red, $S S$, very slight pattern, $P P$, and self red with homozygous variegated, $M M$, showed that these factors are distinct in inheritance. The ratio obtained for the $\mathrm{F}_{2}$ of the self red-pattern cross was $3 \vdots$ I and for the self red-variegated cross was $I: 2: I$. The fact that no new types were produced by these crosses would indicate that $P, M$ and $S$ were multiple allelomorphs. It is impossible to say which is the normal condition from which the other types were produced.

The cross between $M M$ and $P P$ gave results of a different nature. Before discussing these results it may be well to discuss the evidence for purity of the parental types used. Before making the cross the parental varieties were self-pollinated for several generations. The progeny of the self-fertilized ears of the slight pattern type, $P P$, consisted of 2 I9 ears of the pattern type and I ear with a single deep red stripe on one seed. As this ear was open-pollinated it was impossible to determine whether or not this was a germinal variation. The variegated family (69-5) -9 and later self-fertilized generations showed a total of 824 ears all of which were of the variegated type. No ears were produced which did not have a deep red stripe on at least one seed and no ears which were of a higher grade than the medium mosaic class. Within this family self-fertilized medium and light mosaic ears tended, however, to give a larger proportion of ears in the medium and light mosaic class than self-fertilized few stripe ears. Seeds of 6 self-fertilized medium 
mosaic ears which were grown in four successive generations did not materially decrease the range of variegation. Somewhat similar results were obtained in the progeny of 5 self-fertilized light mosaic ears and in the progeny of 3 self-fertilized few stripe ears. There is also no marked uniformity of results for the different types of self-fertilized ears and no indication of definite segregation. These results could be brought into line with EMERson's by supposing a separate factor for medium variegation $M_{m}$ which is allelomorphic to a factor for light variegation $M_{l}$ and by further supposition of frequent germinal variations of $M_{l}$ to $M_{m}$ and vice versa.

As this family breeds true for variegation, we may conclude that it is homozygous for a factor for variegation, or $M M$ (= "mosaic"). The hypothesis of slight germinal variations for the variegated factor seems to be a simpler explanation of the results obtained than the supposition of a definite change from $M_{l}$ to $M_{m}$.

The cross between the variegated type and the very slight pattern type showed a dominance in $F_{1}$ of the variegated race. There was also an increase in variability in $F_{1}$ and ears of a higher grade of variegation were obtained than in the progeny of the homozygous variegated parent. Table I shows that no bud sport ears were obtained in the homozygous parental selections. The $F_{1}$ generation of the cross, however, showed 4 ears of the bud sport type in a total of 144 ears. This is between 2 and 3 percent.

The $F_{2}$ generation of this cross gave a little over $3^{6}$ percent of the progeny in the pattern class, 58 percent of the variegated type, 2 percent bud sports and 4 percent self red pericarp ears. As four different crosses between the pattern and variegated races were studied and as results were of the same nature for each cross, they seem fairly dependable.

If $M$ and $P$ were not allelomorphs some $\mathrm{F}_{2}$ combinations would lack both $M$ and $P$ and presumably lack color in the pericarp. As no such ears were obtained and as there is considerable evidence which seems to show that $M$ and $P$ are respectively allelomorphic to the factor for self color, $S$, there seems to be sufficient reason for concluding that $M$ and $P$ are allelomorphs.

We may then suppose that the union of $M$ and $P$ in $\mathrm{F}_{1}$ causes some sort of contamination which produces a condition of instability. In some cases the $M$ factor may change to the self red form, $S$. The instability of this zygotic combination $M P$ is further shown by the pro- 
duction of a considerable proportion of bud sport ears. As few sports (none having been observed) are produced in the self-fertilized parental forms, $M M$ and $P P$, one might conclude that certain heterozygous combinations produce germinal instability which exhibits itself either as imperfect segregation, gametic contamination or sporophytic variation.

\section{SUMMARY}

Variegated or pattern characters have generally been considered to be of unstable nature. Self-fertilization and selection within a red mosaic pericarp pattern color of maize isolated several types which bred relatively true. The types for pericarp color were self red, variegated, pattern and colorless. Evidence is given which shows that the self red, pattern and colorless selections are homozygous for these characters. The variegated selection proved to be homozygous for the mosaic character and gave a range from ears in which nearly all seeds were heavily striated to ears in which only a few seeds showed red stripes. Extreme plus ears tended to produce a progeny with more ears of the plus type than was obtained in the progeny of few stripe ears. The range of variation, however, was not affected by such selection. These results are explained by the hypothesis of slight germinal variations.

The relation of these various pericarp characters was then studied by making crosses between the various homozygous types. The cross between self red and variegated gave an $F_{1}$ with a more intense variegation than the variegated parent and a ratio of $I: 2: \mathrm{I}$ in $\mathrm{F}_{2}$. The self redpattern cross gave self red ears in $F_{1}$ and a ratio of 3 self red to I pattern in $F_{2}$. The pattern-variegated cross gave an $F_{1}$ with a greater range of variation than either parent. Nearly all ears had a variegated pericarp, several being of a higher degree than the variegated parent. The unstable nature of this cross was further shown by the production of a considerable percentage of bud sport ears. A few self red ears were obtained in $F_{2}$, many variegated ears, nearly half as many pattern ears, as well as a number of bud sport ears. The suggestion is made that certain combinations produce germinal instability. The conclusion is then reached that the factors for self red, variegated, pattern and colorless pericarp form a series of multiple allelomorphs. 


\section{LITERATURE CITED}

CoRREns, C., 1910 Der Übergang aus dem homozygotischen in einen heterozygotischen Zustand im selben Individuum bei buntblättrigen und gestreiftblühenden Mirabilis-Sippen. Ber. d. deutsch. bot. Ges. $28: 418-434$.

DeVries, Hugo, Igro The Mutation Theory. Vol. 2, pp. viii+683. Chicago: The Open Court Pub. Co.

EAst, E. M., ANd Hayes, H. K., IgrI Inheritance in maize. Connecticut Exp. Sta. Bull. 167. pp. 3-142.

Emerson, R. A., I9I4 The inheritance of a recurring somatic variation in variegated ears of maize. Nebraska Research Bull. 4. pp. 3-35.

1917 Genetical studies of variegated pericarp in maize. Genetics 2: 1-35.

Jennings, H. S., I9I6 Heredity, variation and selection in Difflugia. Genetics 1: 407-534.

Stout, A. B., 1915 The establishment of varieties in Coleus by the selection of somatic variations. Carnegie Inst. of Washington $\mathrm{Pub}$. No. 218, pp. 80 . 